\title{
WHO should declare climate change a public health emergency
}

\author{
(C) $(0 \Theta$ OPEN ACCESS
}

Rapid and potentially irreversible climate change poses a direct threat to global public health. Andrew Harmer and colleagues argue that WHO should recognise this in the same way as global threats from specific diseases

\author{
Andrew Harmer senior lecturer in global health ${ }^{1}$, Ben Eder medical doctor ${ }^{2}$, Sophie Gepp medical \\ student ${ }^{3}$, Anja Leetz consultant ${ }^{4}$, Remco van de Pas senior research fellow in global health policy ${ }^{5}$ \\ ${ }^{1}$ Queen Mary University of London, London, UK; ${ }^{2}$ People's Health Movement, London, UK; ${ }^{3}$ Berlin, Germany; ${ }^{4}$ German Alliance for Climate Change, \\ Berlin, Germany; ${ }^{5}$ Institute of Tropical Medicine, Antwerp, Belgium
}

Anthony McMichael first established the link between climate change and human health in the 1990s. ${ }^{1}$ In a distinguished career that established him as a leading authority on the health impacts of climate change, he repeatedly asked whether we understood the profound significance of climate change for global health. ${ }^{2}$ Were we to ask that question today, as we should, the answer would be: We do, but we are failing to act quickly enough or at sufficient scale. ${ }^{3}$

One way to stimulate action is for the World Health Organization to declare climate change a public health emergency of international concern. Several voices have already called for this step. At the opening plenary of the World Health Assembly in Geneva in May 2019, the editor of the Lancet, Richard Horton, urged member states and WHO secretariat to "declare a planetary emergency." A couple of days later, during a side event on air pollution, climate change, oceans, and health sponsored by the Swedish government, the minister of health for the Seychelles, Jean Paul Adam, argued forcefully that: "we have to recognise that climate change is a public health emergency at the international level." We examine how WHO could and should use the authority it derives from its constitution and the International Health Regulations to declare climate change an international public health emergency.

\section{WHO's authority to act on climate change}

WHO's constitution defines health as "a state of complete physical, mental and social well-being and not merely the absence of disease or infirmity." Climate change threatens each of the elements in that definition. It also authorises WHO "to foster the ability to live harmoniously in a changing total environment," and the planet is now experiencing total environmental change. ${ }^{5}$ Furthermore, the constitution allows WHO's executive board "to take emergency measures within the functions and financial resources of the Organisation to deal with events requiring immediate action... and undertake studies and research the urgency [of those events]" (article 28, i). ${ }^{6}$ The Intergovernmental Panel on Climate Change reported in 2018 that we could have as few as 11 years in which to prevent the world from warming beyond $1.5^{\circ} \mathrm{C}$, a temperature threshold that, if breached, will have serious consequences for global health. ${ }^{7}$

The International Health Regulations incorporate a multihazard perspective on health emergencies that enables WHO to assist countries to: "prepare for and respond to a wide range of public health events" resulting from conflict, technological hazard, and natural disasters. ${ }^{8}$ However, the regulations use a very narrow definition of a health emergency. Specifically, a public health emergency of international concern is "an extraordinary event which is determined ... to constitute a public health risk to other States through the international spread of disease and to potentially require a coordinated international response," where event "means a manifestation of disease or an occurrence that creates a potential for disease." ${ }^{\prime \prime}$ In practice, therefore, public health emergencies have been declared only for infectious disease outbreaks, such as the recent outbreak of covid-19. ${ }^{10}$

\section{More than a risk factor}

Under current WHO definitions climate change does not constitute an event appropriate for consideration as a public 
health emergency. Furthermore, WHO's emergency response framework describes climate change as a "risk factor" that can trigger health emergencies rather than an emergency in its own right. ${ }^{11}$

We argue that climate change can no longer be understood merely as a risk factor. It is a totalising event that will, according to WHO's quantitative risk assessment, cause an additional 250 000 deaths between 2030 and $2050 .^{12}$ This figure is an underestimate because of the limited number of health conditions reviewed-malaria, heat exposure in elderly people, diarrhoea, and childhood undernutrition. Food insecurity, for example, could account for a further 529000 adult deaths by $2050 .^{13}$

In terms of mortality, climate change will directly and indirectly lead to a higher number of deaths than all of the previous public health emergencies combined (box 1). Non-communicable diseases such as cancer and cardiovascular stroke also cause considerable mortality, but despite the increase in global burden, non-communicable diseases are unlikely to have the same escalation rate and health impact as climate change will have on the global population. There is clearly a need for an internationally coordinated response to infectious diseases outbreaks, and we fully support the mandate of WHO to declare public health emergencies for such events. However, given the high mortality that will result from climate change, the impact it will have on health systems, and the need to mitigate its effects immediately, we argue that climate change warrants similar treatment.

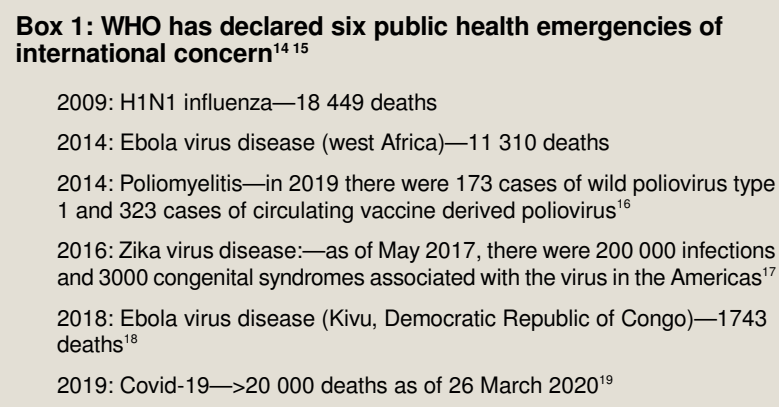

Even within WHO's restricted definition of a health emergency, we argue that climate change satisfies the conditions of a public health emergency of international concern. Increasing heat and precipitation alter the range of disease vectors, increasing it in some locations while decreasing it in others. Climate change thus induces "a potential for disease" by increasing the conditions suitable for disease transmission. The number of people newly at risk of potential viral transmission by the mosquito species Aedes aegypti and A albopictus will approach one billion within this century. ${ }^{20}$ This includes dengue virus, for which global vectorial capacity is increasing "in step" with global carbon dioxide emissions, and yellow fever; both these diseases are mentioned in annex 2 of the International Health Regulations as having the potential to constitute an international public health emergency. ${ }^{21}$ Country borders offer little defence against the global expansion and redistribution of disease, so climate change requires a coordinated international response.

\section{Triggering an emergency}

The International Health Regulations set out the five stages that the director general must consider before declaring a public health emergency of international concern (box 2). The first step is to assess information from member states on events detected by their national surveillance system. In the context of climate change, this information has already been provided in the form of "country profiles" for 45 countries (including six small island states) and will be monitored closely by WHO. ${ }^{22}$ With that information, the director general would seek the advice of the emergency committee, consult scientific evidence, and assess the risk of climate change to human health.

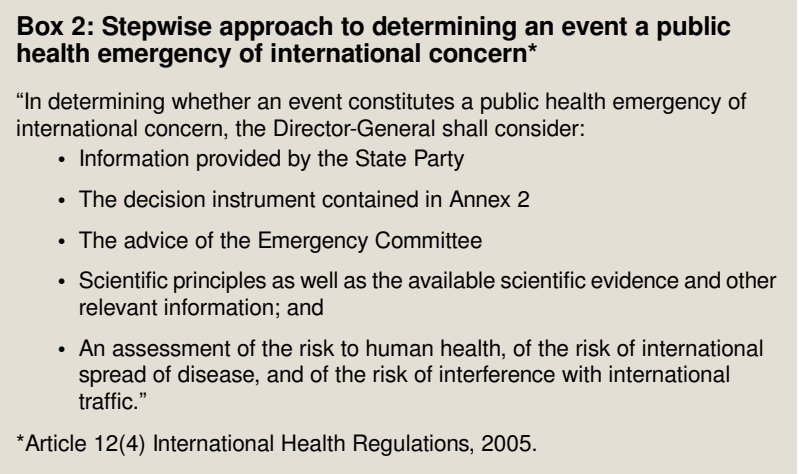

Various disease specific, climate induced events could trigger an international public health emergency. Article 13 of the International Health Regulations puts the responsibility for the response on member states but, in consultation, WHO may offer further assistance, "including an assessment of the severity of the international risk and the adequacy of control measures." In the case of increased Aedes transmitted viruses, an adequate control measure would begin with the implementation of a rapid zero emissions strategy, with the aim of limiting global warming to $1.5^{\circ} \mathrm{C}$, and grounded in principles of climate justice and rights. Though not sufficient, as noted above it could protect one billion people from infection.

\section{Wider definition}

The reality of climate change, however, creates an urgent need to revise the narrow disease-specific definition of an international public health emergency. For example, the term "event" implies a discrete and timebound threat whereas the imminent health threats posed by climate change are protracted, chronic conditions. We therefore support a recent call for WHO to convene "review conferences" of its health regulations to consider how best to tackle health emergencies related to climate change. ${ }^{23}$ In relation to the covid-19 outbreak, one commentator suggested that the regulations' "all-or-nothing approach" towards declaring an international health emergency should include a spectrum of alerts from category 1 to category $5 .^{24} \mathrm{We}$ argue that such flexibility should extend to include threats to global public health that are not disease specific.

The need for the regulations to embrace a broader spectrum of global public health threats is most evident in the context of small island developing states. WHO recognises "the severe and urgent threats to the health and well-being" of 65 million people living in these states, and its draft plan of action presents "a vision that by 2030 , all health systems in small island developing states will be resilient to climate variability and change." ${ }^{25}$ WHO's vision will provide small comfort to those ministers of health who are, literally, watching their homelands sink beneath the waves. As the Marshall Islands' ambassador to the United Nations, Doreen Debrun asked: "Can you imagine having won an independent state only to realise that your children might see it disappear?"26 How resilient will the health systems of states such as the Marshall Islands have to be to cope with a rise in sea level of several metres "within a few centuries"? ${ }^{27}$ In such circumstances, we argue that declaring a public health emergency of international concern could be appropriate. 
WHO's constitution states: "The health of all peoples is fundamental to the attainment of peace and security and is dependent upon the fullest cooperation of individuals and States." It also notes "that healthy development of the child is of basic importance." "The Friday for Future movement of young people all around the world argues that adults are "stealing their future in front of their very eyes." ${ }^{28}$ In November 2019 more than 11000 scientists declared unequivocally "that planet Earth is facing a climate emergency," ${ }^{29}$ while the Lancet's Countdown report concludes: "An unprecedented challenge demands an unprecedented response." ${ }^{3} \mathrm{WHO}$ could provide a strong signal by declaring climate change a public health emergency. By doing so, it would protect and respect its mandate, global public health, the planet, and the wellbeing of present and future generations; it would mobilise political will and funding needed for climate action; and it would convey the urgency of the reality of climate change that we now face. If ever there was a public health emergency of international concern, it is this.

\section{Key messages}

Climate change presents a serious threat to global public health and requires an immediate, internationally coordinated response

WHO could respond to that threat through its mechanism for declaring a health threat a public health emergency of international concern

Current terms and criteria for declaring an international health emergency are primarily disease focused and should be reviewed to include climate change

Declaring climate change an international health emergency could strengthen a coordinated, international response by mobilising political will and funding

Contributors and sources: The arguments presented in this article originate from discussions at a civil society workshop in Geneva in May 2019 organised by Thomas Schwartz of the Geneva Global Health Hub at which $\mathrm{AH}$ gave a presentation. The authors have a wide range of expertise in global health and climate activism. $\mathrm{AH}$ is director of Queen Mary University's BSc in global health. RVP is a lecturer in global health at Maastricht University and research fellow at the Institute of Tropical Medicine in Antwerp. BE and SG are members of the People's Health Movement and active in climate and health organisations in their respective countries. AL has been working in the area of climate policy for several years. $\mathrm{AH}$ proposed the idea and developed the arguments into a full draft. Coauthors commented equally on further drafts and provided input into the revision of argument and provision of content. $\mathrm{AH}$ is the guarantor.

Competing interests: We have read and understood BMJ policy on declaration of interests and have no relevant interests to declare.

Provenance and peer review: Commissioned; externally peer reviewed.

This article is part of a series commissioned by The BMJ. Open access fees are paid by the Institute of Tropical Medicine, Antwerp, which had no involvement in external peer review, editing, or the decision to publish.

1 McMichael AJ. Planetary overload: global environmental change and the health of the human species. Cambridge University Press, 1993.
2 McMichael AJ, Neira M, Bertollini R, Campbell-Lendrum D, Hales S. Climate change: a time of need and opportunity for the health sector. Lancet 2009;374:2123-5. 10.1016/S0140-6736(09)62031-610.1016/S0140-6736(09)62031-6 19942278

3 Watts N, Amann M, Arnell N, etal. The 2019 report of the Lancet countdown on health and climate change: ensuring that the health of a child born today is not defined by a changing climate. Lancet 2019;394:1836-78. 10.1016/S0140-6736(19)32596-6 31733928

4 WHO. 72nd World health assembly —opening ceremony (2019) [video]. https://www. youtube.com/watch?v=695Th9JaFIY\&t=1058s

5 Prescott SL, Logan AC. Down to earth: planetary health and biophilosophy in the symbiocene epoch. Challenges 2017;8:1910.3390/challe8020019.

6 WHO. Constitution of the World Health Organization. Am J Public Health Nations Health 1946;36:1315-23. 10.2105/AJPH.36.11.1315 18016450

7 IPCC. Global warming of $1.5^{\circ} \mathrm{C}$ : summary for policymakers. Intergovernmental Panel on Climate Change, 2018.

8 WHO. IHR (2005): a multi-hazard dimension. https://www.who.int/ihr/public_health concerns/en/.

9 WHO. International health regulations. 3rd ed. World Health Regulations, 2005

10 WHO. Statement on the second meeting of the International Health Regulations (2005) emergency committee regarding the outbreak of novel coronavirus (2019-nCoV), 30 Jan 2020. https://www.who.int/news-room/detail/30-01-2020-statement-on-the-second-meetingof-the-international-health-regulations-(2005)-emergency-committee-regarding-theoutbreak-of-novel-coronavirus-(2019-ncov)

11 WHO. Emergency response framework. 2nd ed. WHO, 2017.

12 WHO. Quantitative risk assessment of the effects of climate change on selected causes of death, 2030s and 2050s. WHO, 2014.

13 Haines A, Ebi K. The imperative for climate action to protect health. N Engl J Med 2019;380:263-73. 10.1056/NEJMra1807873 30650330

14 WHO. Pandemic (H1N1) 2009-update 112. https://www.who.int/csr/don/2010_08_06/ en/

15 WHO. Ebola outbreak 2014-16. www.who.int/csr/disease/ebola/en/

16 Polio Global Eradication Initiative. Polio this week as of 04 March 2020. http:// polioeradication.org/polio-today/polio-now/this-week

17 Baud D, Gubler DJ, Schaub B, Lanteri MC, Musso D. An update on Zika virus infection. Lancet 2017;390:2099-109. 10.1016/S0140-6736(17)31450-2 28647173

18 WHO. Ebola virus disease: Democratic Republic of Congo. Situation report 51, 2019. https://apps.who.int/iris/bitstream/handle/10665/326015/SITREP_EVD_DRC_20190721 eng.pdf?ua $=1$

19 Worldometer. Coronavirus cases, 26 Mar 2020. https://www.worldometers.info/coronavirus

20 Ryan SJ, Carlson CJ, Mordecai EA, Johnson LR. Global expansion and redistribution of Aedes-borne virus transmission risk with climate change. PLoS Negl Trop Dis 2019;13:e0007213. 10.1371/journal.pntd.0007213 30921321

21 Watts N, Amann M, Arnell N, etal . The 2018 report of the Lancet Countdown on health and climate change: shaping the health of nations for centuries to come. Lancet 2018;392:2479-514. 10.1016/S0140-6736(18)32594-7 30503045

22 WHO Draft WHO global strategy on health, environment and climate change: the transformation needed to improve lives and well-being sustainably through healthy environments. Report by the director general. WHO, 2019.

23 Katz R. Pandemic policy can learn from arms control. Nature 2019;575.

24 Piot P. What Ebola teaches us about controlling coronavirus. Time 2020 Feb 6. https:// time.com/5778998/ebola-coronavirus-lessons/

25 WHO. Draft plan of action on climate change and health in small island developing states. Report by the director general. WHO, 2019.

26 IOM, UN Migration. If you believe climate migration is a myth, please listen to this powerful message from Doreen Debrum, ambassador of the Marshall Islands to the UN. 27 Nov, 2019. Retrieved from url of tweet. https://twitter.com/UNmigration/status/ 1199779929971445762

27 IPCC. Summary for policymakers. In: Special report on the ocean and cryosphere in a changing climate. Intergovernmental Panel on Climate Change, 2019.

28 Thunberg $G$ and 46 youth activists. Young people have led the climate strikes. Now we need adults to join us too. Guardian 2019 May 23. heguardian.com/commentisfree/2019/ may/23/greta-thunberg-young-people-climate-strikes-20-september

29 Ripple WJ, Wolf C, Newsome TM, Barnard P, Moomaw W. World scientists' warning of a climate emergency. Bioscience 2020;70:8-1210.1093/biosci/biz152 .

() Author(s) (or their employer(s)) 2019. Re-use permitted under CC BY-NC. No commercial re-use. See rights and permissions. Published by

BMJ.http://creativecommons.org/licenses/by-nc/4.0/This is an Open Access article distributed in accordance with the Creative Commons Attribution Non Commercial (CC BY-NC 4.0) license, which permits others to distribute, remix, adapt, build upon this work non-commercially, and license their derivative works on different terms, provided the original work is properly cited and the use is non-commercial. See: http://creativecommons. org/licenses/by-nc/4.0/. 